\title{
Land use/cover dynamics and its drivers in Gelda catchment, Lake Tana watershed, Ethiopia
}

\author{
Ebrahim Esa Hassen ${ }^{1 *}$ and Mohamed Assen ${ }^{2}$
}

\begin{abstract}
Background: The demand for meeting local food production has caused farmlands to expand at the cost of natural forests and grasslands in the Ethiopian highlands. However, empirical evidences on rate and patterns of LULC dynamics, and major driving forces in highlands of Ethiopia at catchment level were rare to contribute to design effective land management options. This study was to analyze the rate and patterns of LULC dynamics, and identify major driving forces in the Gelda catchment.
\end{abstract}

Results: Six different LULC maps derived from aerial photographs and Landsat images were produced, and comparisons were made. The results indicated that the study catchment has undergone significant LULC alterations and transformations since late 1950s. Farmlands and settlement were expanded by $57.7 \%$ while shrubs, forests and grasslands were declined by $18.6,83.8$ and $53.5 \%$ over the entire study period, respectively. The magnitude of initial grasslands and farmlands converted into degraded land seems small; however these can significantly cause an irreversible damage to the soil resources. The combinations of land reform of 1975, forest development and villagization program 1980s, civil war, frequent changes in political structure, and population pressure were the major driving forces of LULC change.

Conclusion: Therefore, the GIS and remote sensing based change detection matrix analysis technique could provide useful baseline information to understand the spatiotemporal patterns of land use transitions caused by the major driving forces thereby sustainable land management planning is possible.

Keywords: LULC change, Population pressure, Driving forces, GIS, Remote sensing, Change detection

\section{Background}

Local changes in land use and land cover (LULC) affect life support functions and human livelihoods (Lambin et al. 2001; Lambin and Geist 2006). It has diverse environmental impacts by negatively affecting water supply, reservoir storage capacity, agricultural productivity and ecology of a region (Sharma et al. 2011). In most developing countries, the demands for meeting local food production caused agricultural lands expansion at the expense of natural forests and grasslands (Lambin et al. 2003). Local level studies undertaken in highlands

\footnotetext{
*Correspondence: ebrahimesas036@gmail.com; ebroissa@yahoo.com

1 Department of Geography and Environmental Studies, University of Gondar, P.O. Box 196, Gondar, Ethiopia

Full list of author information is available at the end of the article
}

of Ethiopia suggest that a presence of significant LULC changes were caused by a combination of varying factors depending on each locality condition (Hassen et al. 2015; Eyayu et al. 2009; Woldeamlak and Sterk 2005; Eleni et al. 2013; Mohammed 2011; Woldeamlak 2002).

Increased deforestation and poor farm management practices has led to accelerated soil erosion and land degradation in the Ethiopian highlands (Mohammed et al., 2005; Hurni et al. 2005; Hassen et al. 2015). These are, particularly, common in areas where high population pressure exists whose livelihoods directly depend on the exploitation of natural resources in rural areas (Woldeamlak and Sterk 2005). Farmland/settlements and bushlands/degraded lands were expanding appreciably, while grasslands and forest areas have been diminished 
largely driven by population pressures, economic factors and policy issues (Woldeamlak 2002; Getachew et al. 2011; Tsehaye and Mohammed 2013; Eleni et al. 2013; Hassen et al. 2015; Alemu et al. 2015). Similarly, significant expansions of urban built-up were accompanied by substantial decline in forest, grass and shrub lands (Mohammed 2011). These studies supported that LULC changes have implications for environmental degradation such as soil erosion, soil quality deterioration, decreasing available water and the subsequent drying-out of water reservoirs.

Increasing rates of forest conversion, unsustainable agricultural land use and severe soil erosion are the major factors characterizing land degradation in the highlands of Ethiopia (Mekuria 2005). Despite efforts made to overcome deforestation and the resulting land degradation in Ethiopia, as EFAP 1993, the extent of forests was much higher from $40 \%$ at the beginning of the twentieth century, $16 \%$ in the 1950 s, $3.1 \%$ by 1982 , only $2-3 \%$ in 1990 s, and $3.56 \%$ in 2004 (Badege 2001; Wubalem 2012). That means, although the attempts to rehabilitate areas under intense deforestation and degraded as part of national campaign to conserve soil and water in different parts of Ethiopia have been done; success has been limited to date. Accordingly, some remnant stands of natural forests are mainly confined to religious sites, along rivers and streams, and on peaks of hills where crop cultivation is difficult in the highlands of Ethiopia (Warra et al. 2013). This is due to the fact that agriculture and rural settlement has remained the predominant and ever expanding LULC classes between 1965 and 2007 caused by a variety of natural and man-made drivers of change.

The major driving forces of human-induced change in LULC form a complex system of dependencies, interactions and feedback loops at different spatiotemporal scales (Agarwal et al. 2002; Verheye 2007). These complexity calls for multidisciplinary analyses, primarily focused on biophysical attributes (e.g. topographic or soil type), and wide range of socio-economic drivers of change (Veldkamp and Lambin 2001). Driving force of landscape change is determined by the spatiotemporal and institutional scale of the system under study (Bürgi et al. 2004). These driving forces of landscape change involve land cover (climate, topography and soil characteristics) and land use (human induced) processes, such as natural (biophysical) and man-made driving forces, i.e., socioeconomic, political, technological, and cultural (Bürgi et al. 2004; Sherbinin 2002; Lambin et al. 2001). Cultural or man-made drivers may also trigger events as important as biophysical drivers (Lambin et al. 2003).

The mounting pressures on the natural forest, shrubs and grasslands by unsustainable land uses, in the study area, have witnessed spatiotemporal changes in LULC patterns. However, studies of LULC dynamics using change detection analysis to explain the land use transition, i.e., net loss and/or gain of each LULC classes over space and time at this level are rare in the northwestern highlands of Ethiopia. This study is, therefore, crucial for researchers to contribute on the limited literature on the subject by providing empirical evidences on rate and patterns, and major driving forces of LULC dynamics in highlands of Ethiopia at catchment level; which can contribute to design effective land management options. It can also provide insights into the major contributors of land use transitions and a baseline study for examining their implications on soil erosion potential, soil characteristics and suitability status of the land for sustainable rainfed agriculture in the highlands of Ethiopia. Therefore, the main purpose of this analysis is to provide empirical evidences on rate and patterns, and identify major driving forces of LULC dynamics at watershed level; and thereby designing a more effective land management options will be possible.

\section{Materials and methods \\ Study area description}

The Gelda catchment is located between $11^{\circ} 38^{\prime} 14^{\prime \prime}$ and $11^{\circ} 46^{\prime} 15^{\prime \prime} \mathrm{N}$ latitude, and $37^{\circ} 25^{\prime} 54^{\prime \prime}$ and $37^{\circ} 41^{\prime} 29^{\prime \prime} \mathrm{E}$ longitude. It has an area of 26,264 hectares, covering about $2.2 \%$ of the Lake Tana watershed. It is drained by a stream named as Gelda (from where the name of watershed is given) flowing into Lake Tana from west direction (Fig. 1). The landform of the catchment reflects its geological history where uplifting force created an initial elevated landmass and the subsequent outpouring of basaltic lava provided a thick protective cap and added on to the elevation (Eleni et al. 2013). According to the report of Geological Survey of Ethiopia (GSE 1996), the catchment generally comprises materials ranges from alkaline to transitional basalts that often forming shield volcanoes, with minor trachyte and phenolite flows called "Tarmaber Gussa Formation" in southeast and eastern parts of the catchment formed during the Oligocene to Miocene epochs of the Tertiary period. The western and northwestern parts of the catchment consist of alluvial and lacustrine deposits of the Quaternary period.

The altitude ranges from 1780 to 2481 meters above sea level. The slope gradient is dominated by gentle slope $(0-7.6 \%)$ covering about $48.5 \%(12,682 \mathrm{ha})$ and moderately steep (7.7-16\%) with $37.13 \%$ (9714 ha) of the catchment. The steep (16.2-30.2\%) and very steep $(>30.3 \%)$ slope gradients cover about $11.22 \%$ (2936 ha) and 3\% (787 ha) respectively, commonly found in the southeastern and southern corners of the catchment. Gleysols (54.9\%) and Nitisols (30.5\%) form the major soil types of the catchment (FAO 1997). Gleyosols are poorly drained 


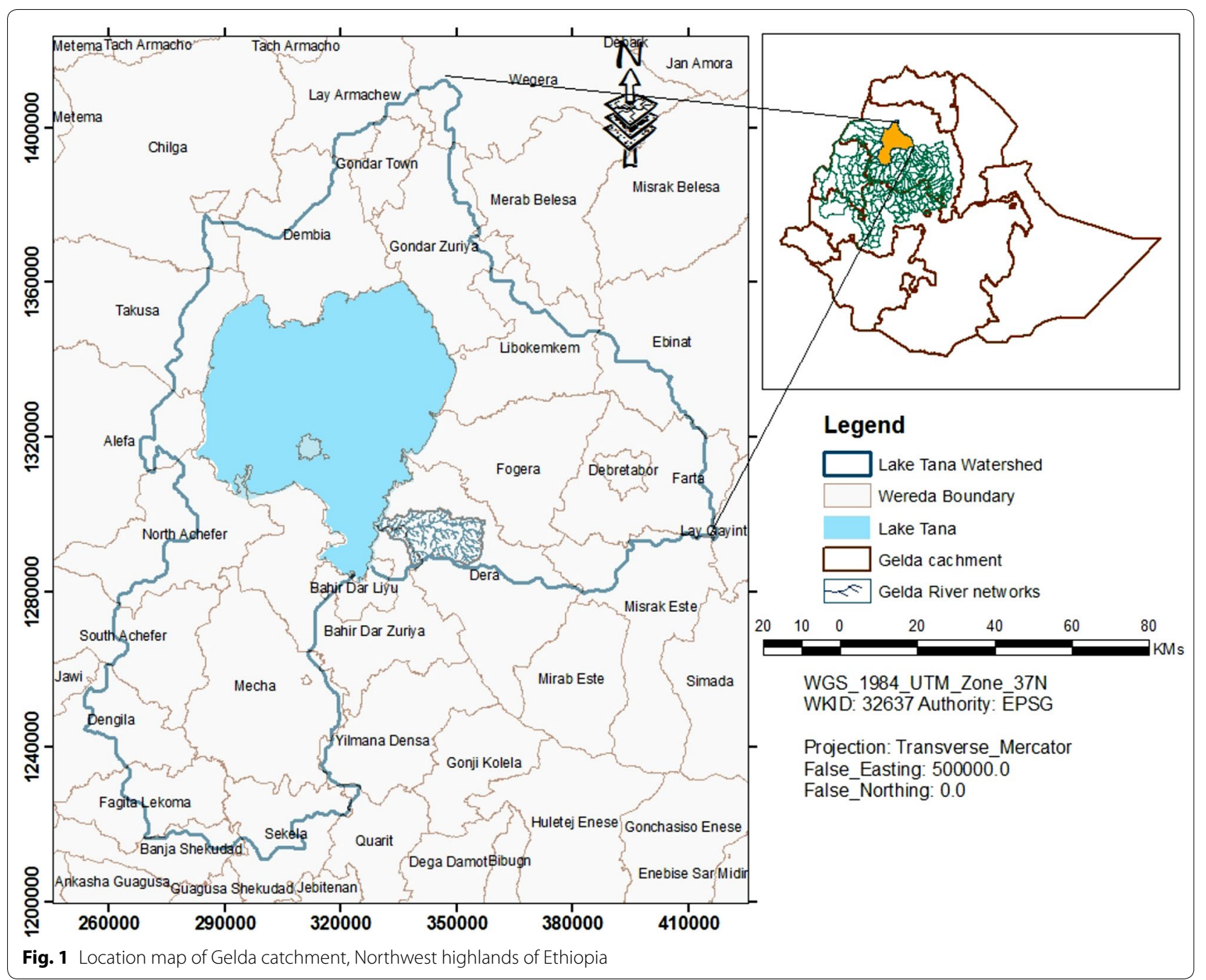

with seasonal water accumulation (Driessen and Deckers 2001). The other soils are commonly found on the sloping lands.

The type of climate is generally sub-tropical with average total annual rainfall amount of $1453 \mathrm{~mm}$ showing a high inter-annual variability (Hurni 1998). The available rainfall records for the period between 1961 and 2014 records showed that the pattern is predominantly unimodal. The main rainy season category, June to October, accounts for about $90 \%$ of the total annual rainfall (Fig. 2). The highest mean monthly temperature $\left(30^{\circ} \mathrm{C}\right)$ is recorded in April whereas the minimum $\left(8^{\circ} \mathrm{C}\right)$ in December with mean monthly range of $5^{\circ} \mathrm{C}$ (Fig. 2).

As evidenced from protected areas like churches and grave yards, climatic-climax vegetation found in the area include Juniperus procera (locally tid), Hagenia abyssinica (locally called kosso); Albizia gummifera (Sassa);
Podocarpus falcatus (Zigba); Cordia africana (wanza); and Ficus vasta (Warka). Field observation also indicated that non-indigenous tree species like Cupressocyparis leylandii (yeferenj Tid), Acacia sieberiana (Yefereng Girar) and Eucalyptus spp. (Bahir zaf) are expanding.

Subsistence rainfed crop production with supplementary traditional irrigation and livestock husbandry are the main sources of livelihood. Dera wereda ARD office (2013) showed that the commonly grown crops in the catchment include barley (Hordeum vulgare L.), maize (Zea mays L.), teff (Eragrotis teff), noug (Guizotia abyssinica), and finger millet (Eleusin coracana).

\section{Data sources and methods of analysis}

Time series black-and-white photographic and Landsat satellite images were the main source of input data for the LULC analysis in this study. The 1957 aerial 


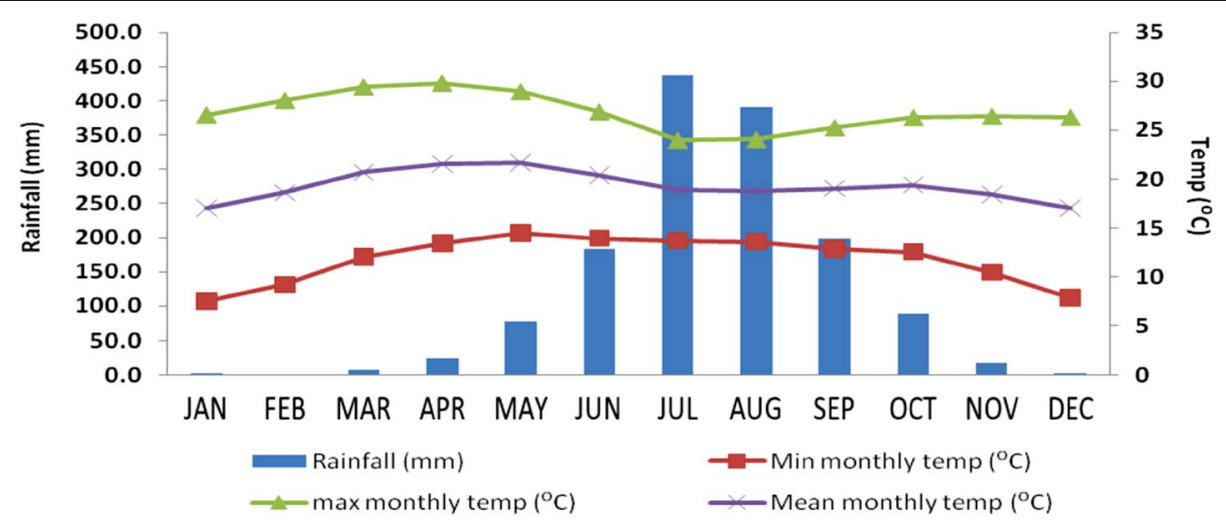

Note: It is based on the records of nearby Bahirdar station (1961-2014) from National

Meteorological service Agency, Ethiopia

Fig. 2 Mean monthly rainfall and mean monthly temperature records of study area

photographic images and 1973 Landsat image were the only oldest remote sensing data available for the study area, but there were no any reference images available between 1957 and 1973. Thus, further subdivisions for LULC analysis between 1957 and 1973 were not possible. Eleven $1 \mathrm{~m} \times 1 \mathrm{~m}$ black-and-white scanned photographic images of 1957 by 600 dots per inch (DPI) were obtained from Ethiopian Mapping Agency (EMA). These were used for photogrammetric processing, as well as visual photo-interpretation activities. Materials such as mirror and pocket stereoscopes were employed for stereo viewing during visual interpretations of features on hardcopy pairs of aerial photos. The visual interpretations process using stereoscopes were helpful to substantiate onscreen feature classifications using GIS environment. Subsequently, all photographic images were geometrically corrected based on geo-referenced and 1:50,000 scale topographic map to produce orthorectified images using "Geo Correction Tools" of ArcGIS. Finally, the mosaic image was produced from eleven orthorectified images using "Mosaic Tool" and later "subset image" into the required study area AOI of ERDAS EMAGINE 9.2.

Landsat images were downloaded from Global Land Cover Facility (GLCF) in the USGS archives at Glovis (http://glovis.usgs.gov). Five images were downloaded at about ten years' interval to easily visualize changes in spatiotemporal LULC patterns. However, some discrepancy \pm 1 year was considered due to the availability and quality of Landsat images from USGS archives for the study area. Therefore, the Landsat MSS of $1973(60 \mathrm{~m} \times 60 \mathrm{~m})$, Landsat TM of 1984 and 1995 $(30 \mathrm{~m} \times 30 \mathrm{~m})$, Landsat ETM+ of $2004(30 \mathrm{~m} \times 30 \mathrm{~m})$ and Landsat OLI of $2014(30 \mathrm{~m} \times 30 \mathrm{~m})$ at path $(169$ and 170p), and row (52r) images were used. These were preprocessed such as layer stacking, sub-sampling the study area by AOI file, re-sampling of all time-series images into similar ground resolution $(30 \mathrm{~m} \times 30 \mathrm{~m})$, gap filling for Landsat 7 SCL-off (2004 and 2014 images), and spectrally enhancing the images before actual image classification process.

The major LULC classes considered in the classification are as given in Table 2. The farm and settlement areas were included in the same land cover as it was difficult to separate these two on the employed images. Likewise, wetland class has been excluded in the classification process as an independent LULC class because this class largely covered with grassland, cultivated fields and forest adjacent to Lake Tana. Consequently, it was difficult to analyze wetlands separately while the area under study is occupied by different LULC classes. About 100 ground control points (GCP) representative of the different LULC classes were taken by a GPS receiver to improve accuracy of classification and to produce thematic land cover maps representative to the entire study period. Field observation was also conducted to substantiate the image classification and analysis.

LULC classification was based on quantitative method that requires an independent classification of time-series images for the same geographic location followed by a comparison of the corresponding pixels to identify and quantify areas of change (Lillesand and Kiefer 1994). Based on the correlation between the collected field data and the preliminary visual interpretation, the entire area was delineated from the orthorectified and geometrically corrected historical aerial photographs of 1957 using on-screen digitization by "Spatial Analysis Tool" of ArcGIS 10. The digitized vector data also have undergone editing, overlay analysis and topological checks. Finally, 
cartographically finished historical LULC maps of 1957 were produced. Conversely, because of low resolution of Landsat images, only major LULC types were considered. Accordingly, supervised classification was done using training areas obtained from ground truth data combined with spectral signatures in false color composite images by maximum likelihood classifier. Subsequently, the accuracy assessment was conducted for all the classified Landsat images (maps) using accuracy assessment tool in ERDAS Imagine 9.2 to evaluate the user's and the producer's accuracy. Thus, the accuracy assessment result indicated that most of the maps met the required minimum $85 \%$ accuracy in LULC analysis as reported in Table 1. This showed a strong agreement between the classified LULC classes and the geographical data (ground truths) and made it possible to use the output maps for change detection analysis.

Once image classifications and accuracy assessment have been completed, six different LULC maps have been produced one in vector format (1957) and the rest in raster format (between 1973 and 2014) where calculation of the area in hectare, comparison of the LULC statistics within and between classes, and years were made possible (Table 2). As a result, the rates of change of LULC classes were determined in terms of percentage by:

$$
C=A_{t 2}-A_{t 1} / A_{t 1} \times 100,
$$

where $A_{t 1}$ is the area of one type of land use in $t_{1}$ time; $A_{t 2}$ is the area of the same type in $t_{2}$ time and $C$ is the rate of

Table 1 Accuracy assessment for the classified images

\begin{tabular}{llll}
\hline $\begin{array}{l}\text { Reference } \\
\text { year }\end{array}$ & $\begin{array}{l}\text { Classified } \\
\text { image }\end{array}$ & $\begin{array}{l}\text { Overall } \\
\text { classification } \\
\text { accuracy (\%) }\end{array}$ & $\begin{array}{l}\text { Overall } \\
\text { kappa } \\
\text { coefficient }\end{array}$ \\
\hline 1973 & Landsat MSS & 86.72 & 0.7478 \\
1984 & Landsat TM & 83.20 & 0.7060 \\
1995 & Landsat TM & 82.42 & 0.6863 \\
2004 & Landsat ETM+ & 95.70 & 0.9285 \\
2014 & Landsat OLI & 88.0 & 0.86 \\
\hline
\end{tabular}

change in percent. This formula is a simple and effective method of weighting the relative rate of change of one LULC class over time where the change directions are determined. Moreover, matrix analyses (image differencing) were employed for images between 1973 and 1995, 1995 and 2004, 2004 and 2014 to determine the LULC change detection using change detection tool in ERDAS Imagine 9.2. However, change detection between 1957 and 1973 was not possible due to incompatibility of 1957 LULC map in the change detection analysis of ERDAS Imagine 9.2. Accordingly, areas that are converted from each LULC class to any of the other over time were computed. The change detection matrix represented the simultaneous gross loss and gain for each LULC class where net losses or gains could be calculated in a given period of analysis. However, field observation and informal interview with the local elders using observation checklist and interview guide were also undertaken in the study area to substantiate the information obtained from GIS and remote sensing based LULC analysis. Therefore, LULC analysis was done using ERDAS Imagine 9.2 and ArcGIS 10 version involved key steps (Fig. 3).

\section{Results and discussion LULC dynamics}

The LULC maps of the catchment for six reference years and the resulting statistical summaries are given in Fig. 4, and Table 3 and 4 respectively.

\section{LULC change in the study catchment between 1957 and 1973}

Table 4 and Fig. 4 indicated an existence of spatiotemporal transformations in the identified LULC classes. Shrinkage of forest cover was observed between 1957 and 1973, while the other LULC classes showed expansions of their original extent in this early period of analysis. Forest cover was declined by $71.5 \%$ (265.2 ha/year) over the time span of 16 years. The shrinkage could be attributed to destruction of natural forests in search for additional farm plots, construction materials and domestic fuel consumption in the study catchment. However, farmland and settlement

Table 2 Description of LULC classes identified in Gelda catchment of Lake Tana watershed, Ethiopia

\begin{tabular}{ll}
\hline LULC classes & Descriptions \\
\hline $\begin{array}{l}\text { Farmland and } \\
\text { settlement }\end{array}$ & $\begin{array}{r}\text { Areas used for crop cultivation, both annuals and perennials, and the scattered rural settlements that are closely associated with } \\
\text { the cultivated fields. These were combined into one category as it was difficult to identify the dispersed rural settlements as a } \\
\text { separated LULC class where fragmented cultivated land exists around homesteads } \\
\text { Forests }\end{array}$ \\
$\begin{array}{l}\text { Fhrubs } \\
\text { included plantation forests mixed with regenerating 'indigenous' species of trees and bushes } \\
\text { Grassland }\end{array}$ & $\begin{array}{l}\text { Areas covered with shrubs, bushes and small trees, with little useful wood, mixed with some grasses } \\
\text { Bare land cover }\end{array}$ \\
\hline
\end{tabular}




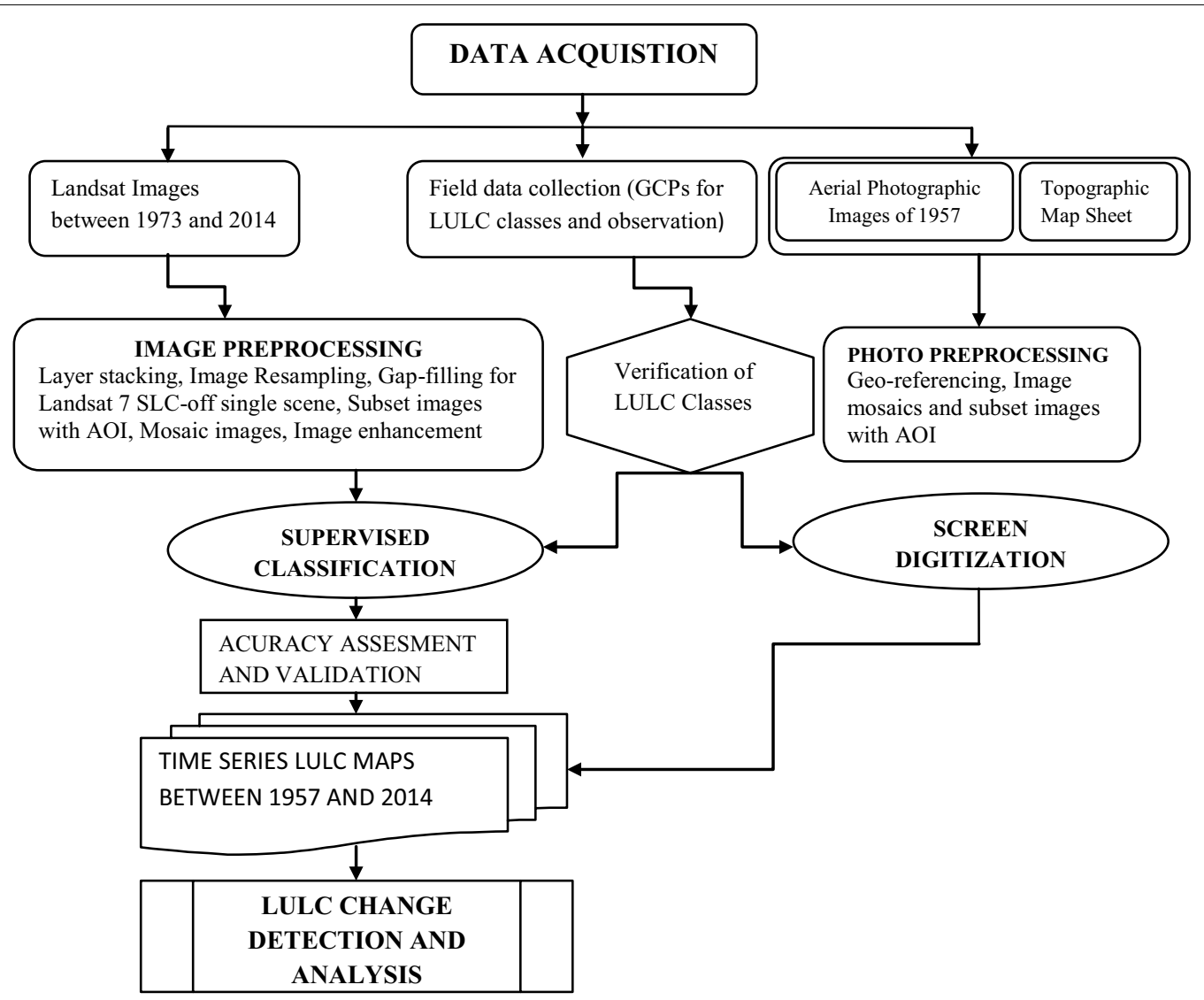

Fig. 3 Schematic representations of LULC change and analysis process

cover, which accounted the lowest coverage ever in the entire 57 years, but has been extended by $12.9 \%$ (73.3 ha/ year). Shrubs accounted for $27 \%$ of the total area of the catchment in 1957 and expanded by 10.2\% (45.5 ha/year). Likewise, grasslands were around $15.8 \%$ of the study area and exceptionally increased by $51.7 \%$ (134.2 ha/year). These possibly reflect the impacts of deforestations on land use transitions where natural forests are ultimately converted into farmlands, shrubs and grasslands between 1957 and 1973. Actual transformed figures of LULC class to other were not given because change detection matrix analysis was not possible.

\section{LULC change in the study catchment between 1973 and 1984}

An expansion of farmland and settlement, forests and bare land were observed between 1973 and 1984 (Table 4). The change detection matrix also indicated similar results although some portions of their original extent were converted into other LULC classes (Table 5). The farmland extended by about 19.24\% (1961.51 ha), giving an annual average expansion of 178 ha/year. The expansion was largely contributed by shrubs by about $32.3 \%$ (3946.1 ha) and grassland by about $15.8 \%$
(1929.56 ha) despite some of the original extent was converted largely into grassland by $16.9 \%$ (1735.59 ha), and shrubs by $26.04 \%$ ( 2660.21 ha). This indicated farmlands were expanded, largely, at the expenses of shrubs and grasslands as the only means of increasing crop production. This expansion could also be attributed to the demand for attaining of food crops and more settlement land (Fig. 5). This suggests that food crop production under the then period of Ethiopian situation could have been obtained through farmland expansions; which is a sign of poor land productivity as well as leading to destruction and farming of non-cultivated lands such as grazing, shrubs and wetlands.

The exceptional increment of forests by $20.06 \%$ (338.87 ha) was largely due to additional areas obtained from grassland by $13.7 \%$ (277.56 ha), farmland and settlement by $18.7 \%$ (379.82 ha), and shrubs by $37.75 \%$ (765.94 ha) despite some of the original cover was lost largely into farmland and settlement by $52.98 \%$ (895.27 ha) and shrubs by $6.97 \%$ (117 ha). This suggests that land acquisition from other LULC classes for forest conservation program was in response to initiatives of restoring indigenous trees and forests by the past 

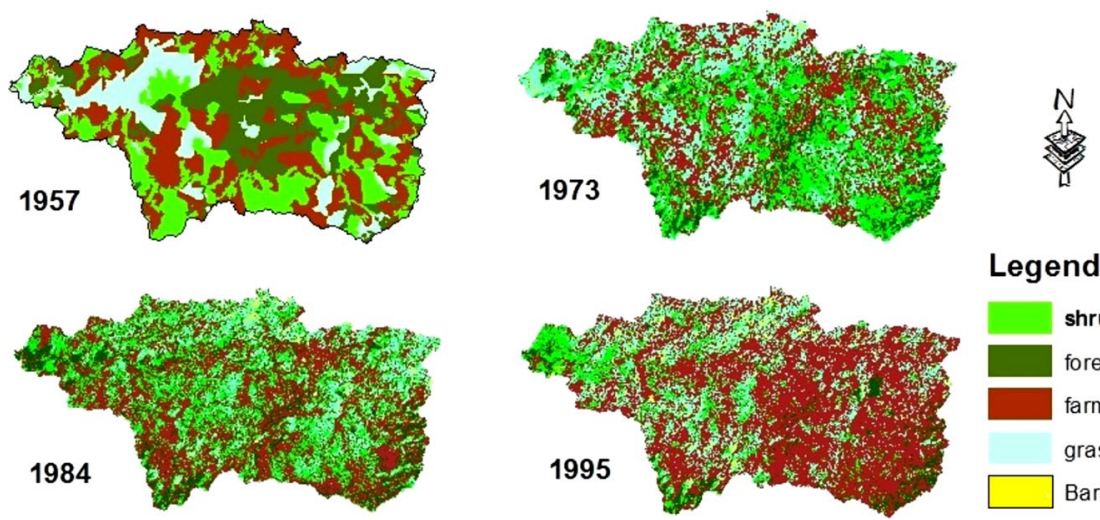

\section{Legend}
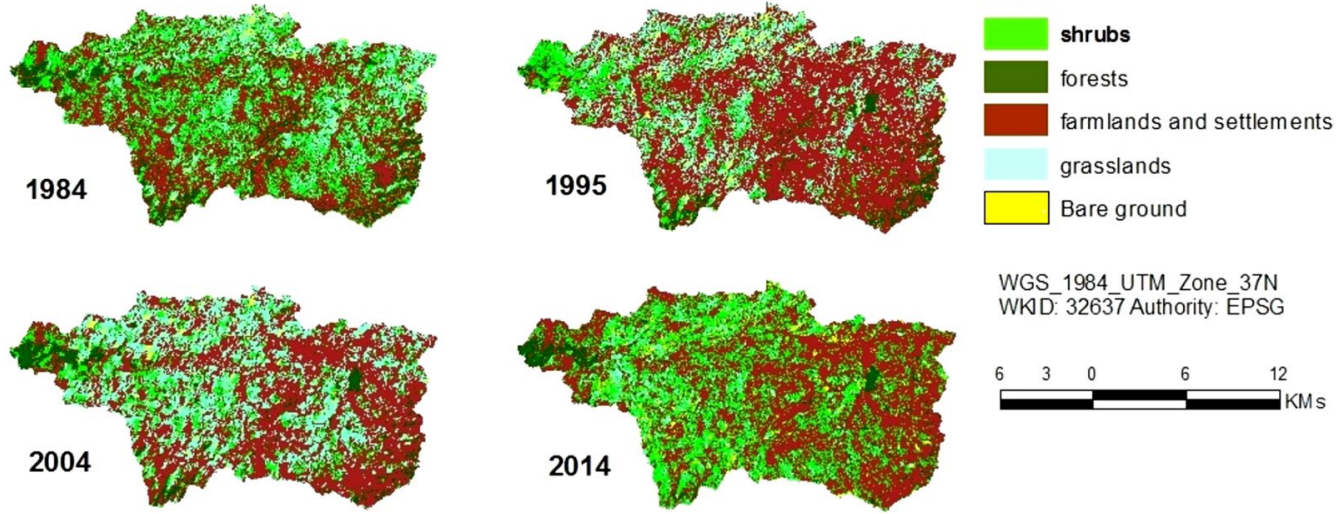

WGS 1984 UTM Zone $37 \mathrm{~N}$ WWD: 32637 Authority: EPSG

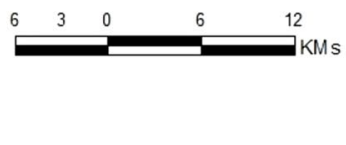

Fig. 4 Land use and cover maps of Gelda Catchment between 1957 and 2014

Table 3 Land use/cover patterns of Gelda catchment between 1957 and 2014

\begin{tabular}{|c|c|c|c|c|c|c|c|c|c|c|c|c|}
\hline \multirow[t]{2}{*}{ LUT type } & \multicolumn{2}{|l|}{1957} & \multicolumn{2}{|l|}{1973} & \multicolumn{2}{|l|}{1984} & \multicolumn{2}{|l|}{1995} & \multicolumn{2}{|l|}{2004} & \multicolumn{2}{|l|}{2014} \\
\hline & Area (ha) & $\%$ & Area (ha) & $\%$ & Area (ha) & $\%$ & Area (ha) & $\%$ & Area (ha) & $\%$ & Area (ha) & $\%$ \\
\hline Shrubs & 7136.50 & 27.17 & 7863.68 & 29.94 & 7292.65 & 27.77 & 2798.39 & 10.65 & 2915.28 & 11.1 & 8464.5 & 32.2 \\
\hline Forest cover & 5932.23 & 22.59 & 1689.68 & 6.43 & 2028.55 & 7.72 & 961.5 & 3.66 & 1247.4 & 4.75 & 959.31 & 3.65 \\
\hline Farmland and settlement & 9044.04 & 34.44 & 10216.3 & 38.90 & 12181.81 & 46.38 & 16255.2 & 61.89 & 13882.86 & 52.86 & 14260.95 & 54.3 \\
\hline Grassland & 4150.42 & 15.80 & 6298.4 & 23.98 & 4560.1 & 17.36 & 5868.03 & 22.34 & 7933.32 & 30.2 & 1931.67 & 7.35 \\
\hline Bare land cover & 0 & 0 & 196.2 & 0.75 & 201.51 & 0.77 & 380.88 & 1.45 & 286.11 & 1.09 & 648.54 & 2.47 \\
\hline Total area & 26264.00 & 100 & 26264.26 & 100 & 26264.62 & 100 & 26264 & 100 & 26264.97 & 100 & 26264.97 & 100 \\
\hline
\end{tabular}

Table 4 Rate of change in LULC between 1957 and 2014 in Gelda catchment

\begin{tabular}{|c|c|c|c|c|c|c|c|c|c|c|}
\hline \multirow[t]{2}{*}{ LUT types } & \multicolumn{2}{|c|}{$1957-1973$} & \multicolumn{2}{|c|}{ 1973-1984 } & \multicolumn{2}{|c|}{ 1984-1995 } & \multicolumn{2}{|c|}{ 1995-2004 } & \multicolumn{2}{|c|}{ 2004-2014 } \\
\hline & Area (ha) & $\%$ & Area (ha) & $\%$ & Area (ha) & $\%$ & Area (ha) & $\%$ & Area (ha) & $\%$ \\
\hline Shrubs & 727.18 & 10.19 & -571.03 & -7.26 & -4494.26 & -61.63 & 115.2 & 4.11 & 5549.22 & 190.35 \\
\hline Forest cover & -4242.55 & -71.52 & 338.87 & 20.06 & -1067.05 & -52.60 & 284.22 & 29.51 & -288.09 & -23.1 \\
\hline Farmland and settlement & 1172.26 & 12.96 & 1965.51 & 19.24 & 4073.39 & 33.44 & -2374.02 & -14.6 & 378.09 & 2.72 \\
\hline Grasslands & 2147.98 & 51.75 & -1738.3 & -27.60 & 1307.93 & 28.68 & 2063.61 & 35.16 & -6001.65 & -75.65 \\
\hline Bare land & - & - & 5.31 & 2.64 & 179.37 & 89.01 & -94.77 & -24.88 & 362.43 & 126.68 \\
\hline
\end{tabular}

socialist regime's forest development program since the establishment of Gelda protected forest in 1980. Similarly, bare land cover also expanded due to major area gain from conversion of grasslands by about $59.2 \%$ (119.6 ha), and farmland and settlement by about $29.3 \%$ (59.35). The expansion of bare land reflected the impact of unsustainable utilizations of grasslands and farmlands due to overgrazing and land degradation.

Shrinkages were observed in the extent of grasslands by $27.6 \%$ (158 ha/year) and shrubs $7.26 \%$ (52 ha/year) despite some gains were obtained from other LULC classes (Table 4 and 5). It is because some areas gained 
Table 5 LULC change matrix of the study catchment (1973-1984)

\begin{tabular}{|c|c|c|c|c|c|c|}
\hline \multicolumn{7}{|c|}{ Change from LULC 1984 (ha) } \\
\hline & Shrubs & Forest cover & $\begin{array}{l}\text { Farmland and } \\
\text { settlement }\end{array}$ & Grassland & Bare ground & Total \\
\hline \multicolumn{7}{|l|}{ Change from LULC 1973 (ha) } \\
\hline Shrubs & 2269.77 & 765.94 & 3946.1 & 875.56 & 9.75 & 7863.68 \\
\hline Forest cover & 174.75 & 580.86 & 895.27 & 38.56 & 0.02 & 1689.68 \\
\hline Farmland and settlement & 2660.21 & 379.82 & 5381.31 & 1735.59 & 59.35 & 10216.3 \\
\hline Grassland & 2136.44 & 277.56 & 1929.56 & 1835.23 & 119.6 & 6298.4 \\
\hline Bare ground & 55.87 & 14.23 & 37.94 & 75.34 & 12.86 & 196.2 \\
\hline Total & 7297.04 & 2018.41 & 12190.18 & 4560.28 & 201.58 & Total \\
\hline
\end{tabular}

N.B. Entries on the cell of the matrix along the diagonal in italic indicated no change was observed in LULC classes, i.e., no loss or no gain

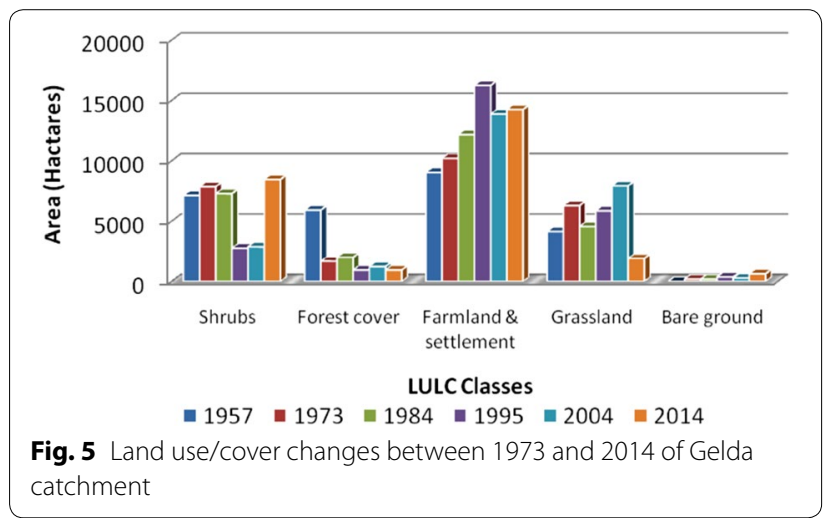

areas from different LULC classes could not bring a net expansion in grasslands and shrubs or did not compensate its decline in this second period of analysis. The substantial decline for grasslands were largely contributed by conversion of its original extent into farmland and settlement 30.63\% (1929.56 ha) and shrubs by $33.92 \%$ (2136.44 ha) despite some gains were observed mainly from farmland and settlement by $38 \%$ (1735.59 ha) and shrubs by $19.2 \%$ ( 875.56 ha). This was attributed to land acquisition for farmlands following the downfall of the imperial regime in 1974 and the resulting policy changes at the expense of grazing lands and shrubs. This also showed the increasing demand for farmlands as well as forest development into areas once occupied by grassland. In addition, shrinkage of shrubs were largely due to conversion of its original extent into farmlands and settlement by about $50.2 \%$ (3946.1 ha) despite some area gains were observed mainly from grasslands, and farmland and settlement by about $29.3 \%$ (2136.44 ha) and $36.48 \%$ (2660.21 ha), respectively. This clearly showed that about half of the original shrubland were transformed into farmland and settlement caused by population pressure and changes in land tenure system that transformed landless tenants into land owners.

\section{LULC change in the study catchment between 1984 and 1995}

LULC study between 1984 and 1995 showed expansion of grassland, farmland and settlement, and bare land despite some area were lost into other LULC classes (Tables 4, 6). The area devoted to farmland and settlement showed a steady expansion by about $33.44 \%$ (370.3 ha/year) in this third period of analysis. Change detection matrix also indicated that the most important contributors of farmlands and settlement expansions were grasslands by about $11.93 \%$ (1940.02 ha) and shrubs by about $24.15 \%$ ( 3925.9 ha) despite some of its initial extent was transformed into other LULC classes (Table 6). This indicated that expansions were at the expenses of grasslands and shrubs cover. A remarkable expansions were also observed in bare land by about $89 \%$ (16 ha/year) and grasslands by about $28.67 \%$ (118.9 ha/ year). The expansion of bare land was due to area gain obtained largely from grasslands by about $48.27 \%$ (183.85 ha). This showed that unsustainable grassland management in the form of uncontrolled grazing attributed to the transformations of its initial grassland cover into bare soil areas. As a result, expansions in grasslands were observed largely due to farmland and settlement by about $28.6 \%$ ( 1680.4 ha), and shrubs by about $33.66 \%$ (1975.4 ha) despite some its initial extent was mainly converted into farmland and settlement. This possibly forced the local farmers to prepare grasslands meant for grazing converted largely from their farmlands and shrubs.

Shrinkages were evident in forest cover 52.6\% (97 ha/year) and shrubs $61.63 \%$ (408.6 ha/year) despite some area gains were observed from other LULC classes (Tables 4, 6). It was because the area gained from other LULC classes could not satisfy the losses or conversions from their original extent. The dominant reasons that largely contributed to the reduction of forest cover were conversion of its initial extent into farmlands and settlement by about $47.37 \%$ (960.98 ha), and shrubs by about $19.26 \%$ (390.8 ha) despite some gains from farmland and settlement. It was partly attributed to forced 
Table 6 LULC change matrix of the Gelda catchment (1984-1995)

\begin{tabular}{|c|c|c|c|c|c|c|}
\hline \multicolumn{7}{|c|}{ Change from LULC 1995 (ha) } \\
\hline LUT & Shrubs & Forest cover & $\begin{array}{l}\text { Farmland and set- } \\
\text { tlement }\end{array}$ & Grassland & Bare ground & Total \\
\hline \multicolumn{7}{|l|}{ Change from LULC 1984 (ha) } \\
\hline Shrubs & 1246.05 & 74.18 & 3925.9 & 1975.4 & 71.1 & 7292.63 \\
\hline Forest cover & 390.8 & 633.64 & 960.98 & 40.34 & 2.79 & 2028.55 \\
\hline Farmland and settlement & 859.48 & 241.01 & 9335.5 & 1680.4 & 65.42 & 12181.81 \\
\hline Grassland & 280.5 & 14.14 & 1940.02 & 2113.65 & 183.85 & 4532.16 \\
\hline Bare ground & 48.32 & 0 & 59.44 & 0 & 93.96 & 201.72 \\
\hline Total & 2825.15 & 962.97 & 16221.84 & 5809.79 & 417.12 & Total \\
\hline
\end{tabular}

N.B. Entries on the cell of the matrix along the diagonal in italic indicated no change was observed in LULC classes, i.e., no loss or no gain

resettlement program between 1987 and 1991. This could be due to forest clearing in search for additional farmlands and new settlement units in socialist regime, particularly during rural resettlement program. The demand for local construction material and fuel wood, and civil war between 1990 and 1991 were the other reasons for forestland decrease. Shrubs have also been diminished as a result of conversion of its initial extent largely into grasslands by about 27\% (1975.4 ha) and farmland and settlement by about $53.8 \%$ (3925.9 ha) despite some gains in farmland and settlement. It was partly related to political instability and change of political structure of the country, which led to the clearance of shrubs for expansion of farmlands and new settlement centers. These revealed that further vegetation clearance in search for additional farmlands, new settlement units and grazing could eventually transform the initial extents of shrubs.

\section{LULC change in the study catchment between 1995 and 2004}

The area under forests, shrubs and grazing lands has been expanded by about 29.51\% (31.58 ha/year), $4.11 \%$ (12.8 ha/year) and $35.16 \%$ (229.3 ha/year) although some portions of their initial extent were converted into other LULC classes, respectively (Tables 4, 7). In this study period, expansion of grasslands was dominantly attributed to conversions of farmland and settlement by about 52\% (4125.97 ha) despite some of the initial extent was largely converted into farmlands and settlement by about $31.2 \%$ (1834.12 ha). It was possibly due to land restoration that were illegally encroached by local community following the political vacuum since early 1990s. The forest cover has also been expanded mainly due to area gains from shrubs by about $28.4 \%$ (354.97 ha), and farmland and settlement by about 28.2\% (351.86 ha) despite some portions of the initial extent of was simultaneously converted mainly into farmland and settlement. Similarly, the expansions of shrubs were largely contributed by farmlands and settlement by about $37.7 \%$ (1097.79 ha), and grasslands by about $25.7 \%$ (749.4 ha) despite some of the initial extents were converted mainly into farmland and settlement, grasslands, and forest cover by about $32.96 \%$ (922.61 ha), $17.6 \%$ (493 ha), and 12.7\% (354.5 ha), respectively. This could be the collapse of the newly established villages following the downfall of the socialist regime and vegetation regeneration in areas that were under intense pressure by local community.

Table 7 also revealed that reductions were observed in farmland and settlement, and bare land because the added areas from other LULC classes could not be adequate to compensate the losses. Exceptional shrinkage

Table 7 Land use and cover change matrix of the Gelda catchment (1995-2004)

\begin{tabular}{|c|c|c|c|c|c|c|}
\hline \multicolumn{7}{|c|}{ Change from LULC 2004 (ha) } \\
\hline LUT & Shrubs & Forest cover & $\begin{array}{l}\text { Farmland and settle- } \\
\text { ment }\end{array}$ & Grassland & Bare ground & Total \\
\hline \multicolumn{7}{|l|}{ Change from LULC 1995 (ha) } \\
\hline Shrubs & 1012.92 & 354.97 & 922.61 & 493.65 & 14.24 & 2798.39 \\
\hline Forest cover & 30.06 & 474.39 & 404.8 & 17.43 & 34.85 & 961.53 \\
\hline Farmland and settlement & 1097.79 & 351.86 & 10634.7 & 4125.97 & 44.9 & 16255.19 \\
\hline Grassland & 749.39 & 42.93 & 1834.12 & 3086.21 & 154.39 & 5867.04 \\
\hline Bare ground & 23.76 & 7.65 & 68.49 & 208.8 & 72.18 & 380.88 \\
\hline Total & 13882.86 & 2915.28 & 286.11 & 7933.32 & 1247.4 & Total \\
\hline
\end{tabular}

N.B. Entries on the cell of the matrix along the diagonal in italic indicated no change was observed in LULC classes, i.e., no loss or no gain 
was observed in farmland and settlement cover by about $14.6 \%$ (263.78 ha/year) possibly due to tough measures taken by the government to restore areas which were under forests, shrubs, grazing lands and those farmlands not suitable for agriculture (Table 4). The dominant contributors of the existing decline in farmland and settlement was associated with the conversions of its initial extent into grasslands by about $25.4 \%$ ( $4125.97 \mathrm{ha}$ ) and shrubs by about $6.7 \%$ (1097.79 ha) despite some area was largely gained from grasslands (Table 7). The areas previously occupied by farmlands and villages were declined following refusal of forced settlement and inadequate reaction from the transitional government in early 1990s. However, tough measures on land restoration were taken at the end of this study period that substantially reduced areas occupied by farmlands. Despite the fact that bare land constituted a very small spatial extent in the watershed, its original extent was decreased as much as $24.9 \%$ at the rate of $10.5 \mathrm{ha}$ /year (Table 4). The decline was contributed mainly by the conversion of the initial extent into grasslands by about $54.8 \%$ ( $208.8 \mathrm{ha})$. This indicated that once the area is out of production and physically unsuitable for either of human uses, the area were exempted from any human contact and eventually recovered largely into grasslands.

\section{LULC change in the study catchment between 2004 and 2014}

Tables 4 and 8 revealed that the highest rate of expansion was observed in shrubs by about $190.35 \%$ ( 555 ha/ year) followed by bare land by about $126.7 \%$ (36 ha/ year), and farmland and settlement by about $2.72 \%$ (38 ha/year) despite some of their original extent was largely converted into other LULC classes. In this last period of analysis, the expansion of farmland and settlement was observed due to areas mainly gained from shrubs by about $6.5 \%$ ( 924.75 ha) and grasslands by about $22.8 \%$ (3259.98 ha) although some of the initial extent of has been largely converted into shrubs by about $25.5 \%$
(3534.84 ha). This lowest rate of increment was reflected in the expansion of eucalyptus and other trees planted at household level around homesteads, development of area closure, and other conservation measures in the study catchment. The Amhara region land reform with the premise of redistributing the land among farmers driven by population pressure and social injustice was also possibly attributed to farmland expansion at the expense of other LULC classes. Similarly, shrubs has been expanded largely due to areas gained from farmland and settlement by about $41.8 \%$ ( $3534.84 \mathrm{ha})$, and grasslands by about $39.9 \%$ (3377.97 ha) despite some of its initial extent was converted into farmlands and settlement by about $31.7 \%$ (924.75 ha). This could be the results of recent attempts of area closure and forest restoration, which subsequently transformed into shrubs. However, expansion in bare land was largely due to area gained from grasslands by about 57.5\% (372.78 ha), and farmland and settlement by about $34.6 \%$ (224.46 ha). This could be the impacts of poor farmland practices and overgrazing.

Slight decline was observed in forest cover by $23.1 \%$ $(28.8 \mathrm{ha} / \mathrm{y})$ while the highest was in grazing lands by 75.65\% (600 ha/year) between 2004 and 2014 (Table 4). These shrinkages were evident because some areas gained from other LULC classes were not adequate to compensate the losses from their initial extent (Table 8). Decline in forest cover was largely attributed to its conversion into farmland and settlement by about $43.5 \%$ ( $543.3 \mathrm{ha}$ ) and shrubs by about $8.5 \%$ (106.4 ha) despite some area gain from the classes of shrubs by $10.7 \%$ (102.6 ha), and farmland and settlement by $26.1 \%$ ( $250 \mathrm{ha}$ ). In this study period, various levels of vegetation clearance in search for farmlands and household consumption have possibly transformed the original forest cover into farmlands and shrubs. Similarly, reduction in grassland covers were mostly caused by conversion of its initial extent into shrubs by about $42 \%$ (3377.97 ha), and farmland and settlement by about $41.1 \%$ (3259.98 ha) despite some gains from other LULC classes. This was possibly associated to

Table 8 Land use and cover change detection matrix of the Gelda catchment (2004-2014)

\begin{tabular}{|c|c|c|c|c|c|c|}
\hline \multicolumn{7}{|l|}{ Change to LULC 2014 (ha) } \\
\hline LUT & Bare ground & Shrubs & Grassland & Forest cover & Farmland and settlement & Total \\
\hline \multicolumn{7}{|l|}{ Change from LULC 2004 (ha) } \\
\hline Bare ground & 32.85 & 102.42 & 117.18 & 0.63 & 33.03 & 286.11 \\
\hline Shrubs & 17.73 & 1342.89 & 527.31 & 102.6 & 924.75 & 2915.28 \\
\hline Grassland & 372.78 & 3377.97 & 892.35 & 30.24 & 3259.98 & 7933.32 \\
\hline Forest cover & 0.72 & 106.38 & 21.15 & 575.82 & 543.33 & 1247.4 \\
\hline Farmland and settlement & 224.46 & 3534.84 & 373.68 & 250.02 & 9499.86 & 13882.86 \\
\hline Total & 648.54 & 8464.5 & 1931.67 & 959.31 & 14260.95 & Total \\
\hline
\end{tabular}

N.B. Entries on the cell of the matrix along the diagonal in italic indicated no change was observed in LULC classes, i.e., no loss or no gain 
Table 9 Rate of change of LULC for the past 57 years (1957-2014)

\begin{tabular}{|c|c|c|c|c|c|}
\hline LULC classes & Shrubs & Forest cover & Farmland and settlement & Grassland & Bare land \\
\hline \multicolumn{6}{|c|}{ Rate of changes } \\
\hline Area & 1328 & -4972.92 & 5216.91 & -2218.75 & 648.54 \\
\hline$\%$ & 18.60856 & -83.8288 & 57.6834 & -53.4584 & - \\
\hline
\end{tabular}

land encroachment for agriculture and land restoration which was not suitable for grazing into shrubs.

LULC change in the study catchment between 1957 and 2014 Table 9 demonstrated that shrubs, farmlands, and bare lands were expanded while grassland and forest cover were contracted over the past 57 years in the study area. Despite the forest plantation and conservation effort since 1980 in the catchment, forest cover has declined by about $83.83 \%$ ( $87.2 \mathrm{ha} /$ year). It is because of the small success achieved by the government to fully cover the areas that were under poor management and exhaustively used. Although areas under grazing lands showed an irregular pattern of spatiotemporal variations, it has shown a decline by about $53.46 \%$ ( 38.9 ha/year) over the entire study period. However, the patterns of changes in areas under shrubs indicated that it has shown an expansion by about $18.6 \%$ (23.3 ha/year), which was partly attributed to the impacts of planting trees for household consumption around homesteads by local community; and recent campaign in soil and water conservation activities since 2011. The area under bare land contained less than $3 \%$ of the total area of the catchment; however the trend in its area showed that it has exceptionally expanded by about 11.37 ha/year. Farmland and settlement was expanded by about $57.68 \%$ (91.5 ha/year). This highest trend of expansion in bare land suggests the presence of unsustainable land management practices while farmland expansion was largely at the expenses of the natural forest cover and grasslands.

\section{Major drivers of land use and cover dynamics}

The LULC dynamics in the study area largely depend on dynamic relationships among population and policy/ institutional factors, but the effect of natural factors such as climate over small area and short periods of time may not felt as such.

\section{Population pressure}

Although the overall demographic data for the study catchment was not possible to obtain following catchment boundaries, the data were compiled according to administrative structure where the catchment is almost entirely found. The demographic data were limited to three census reports of Ethiopia in 1984, 1994 and 2007; but LULC analyses were between 1957 and 2014. Thus, demographic data were used to see trends of population changes in the study area over larger portion of the study period so that comparison can be made possible among LULC change and population pressure. The data indicated that the total population of Dera wereda was increased from 204,962 in 1984; 212,341 in 1994 to 248,464 in 2007 at an average annual growth rate of 3.6 and $16.9 \%$ respectively (CSA 1991, 1995, 2008). This revealed that population pressure on the land resources increased the demand for farmlands, settlements, fuel wood, and construction materials. The census reports also indicated that most of the total population in the were da (>90\%) resides in the rural areas where households largely depend on land resources as means of livelihood. This caused expansion of farmlands into shrubs, forests and grasslands; overgrazing; deforestation for household energy consumption and income; and declined arable land percapita in rural areas. These suggest that population growth is a major driving force in LULC dynamics of Gelda catchment. This is consistent with the previous studies in the highlands of Ethiopia (Woldeamlak 2002; Wubalem 2012; Hurni 1988; Mekuria 2005; Tsehaye and Mohammed 2015; Hassen et al. 2015). However, direct field observation and informal interview indicated that the scarcity of forest products for household consumption forced the local population to plant trees around homesteads and protect forests in areas not usable for agriculture in recent times. The expansion of farmlands and bare land in the study area were presumably attributed to the impacts of population pressure mainly in search of additional farmlands, overgrazing and poor farming practices. Sociopolitical influences, especially inse-curity of land tenure; disincentives among farmers for conservation programs; taking some land out of production and placing more pressure on existing farm and grasslands have discouraged farmers from investing in soil conservation practices since 1984 in the study area.

\section{Institutional and policy factors}

Ethiopia has undertaken many institutional and policy changes regarding land resources management following major changes in political and government structures in 1974, 1974 and 1991. These frequent changes in political and government structures were responsible for successive changes in land resource use and administrative 
frameworks in Ethiopia, which intern resulted in successive LULC changes in the study area. The major institutional and policy factors responsible for changes in LULC change were the downfall of the imperial regime followed by land reform of 1975 where farmlands were given to landless tenants confiscated from landlords, and clearing forest and shrubs. The forest restoration and plantations program of socialist regime since early 1980s using food-for-work program was another policy factor where success to date is rare due to lower local community involvement. The resettlement program between 1987 and 1990; civil war between 1990 and 1991; downfall of socialist regime; and the resulting legal vacuum in natural resource conservation attributed to the clearance of shrubs and forest cover. The 1997 land redistribution in Amhara region that aimed at ensuring social justice and responding to population change was another factor despite its failure to fully satisfy the ever increasing demand for farmlands and settlement.

\section{Conclusion}

There have been substantial LULC changes in Gelda catchment of northwestern highlands of Ethiopia driven mainly by population pressure institutional and policy factors. The existing expansions of traditional farming practices into grasslands, natural vegetations and marginal lands eventually led to a decrease in fodder availability and gradual soil quality deterioration. The decline in grassland forced the local community to keep their cattle on bare lands and shrubs, particularly during the cropping season. The institutional and policy reforms over the entire study period have contributed to changes the legal and policy frameworks of land resource management and ownerships in the country. These changes could have implications for sustainable agricultural resource management and the livelihood of the local community. As a result, off-farm activities and soil fertility improvement are essential to reduce the adverse impacts of population pressure on natural resource base. Improved land management practices such as applying soil and water conservation techniques and improved agricultural inputs could improve agricultural production. Likewise, local involvement in natural resource management and the existence of clear land tenure policies are critical for sustainable land use. Alternative energy sources for household energy consumption and environmental education are also imperative. Therefore, the change detection matrix analysis in GIS and remote sensing could provide useful baseline information to understand the spatiotemporal patterns of land use transitions and major contributors of LULC change caused by the major driving forces thereby sustainable land management planning is possible.

\section{Authors' contributions}

EEH has conceived of the study. He has also participated in the design of the study, carried out the data collection, GIS and remote sensing based analysis of data, and performed the statistical analysis. MA has participated in the sequence alignment of the draft manuscript. He also participated in its design and coordination, and helped to draft and edits the manuscript. All authors read and approved the final manuscript.

\section{Author details}

1 Department of Geography and Environmental Studies, University of Gondar, P.O. Box 196, Gondar, Ethiopia. ${ }^{2}$ Department of Geography and Environmental Studies, Addis Ababa University, P.O. Box 150116, Addis Ababa, Ethiopia.

\section{Acknowledgements}

The authors are grateful to Addis Ababa University (Addis Ababa, Ethiopia) and University of Gondar (Gondar, Ethiopia) for their financial and operational support to conduct this research. This study was also made possible by a research grant awarded to the first author by Association of African Universities (Accra, Ghana).We also thank the local farmers in the study area for their cooperation and understanding during field work. The paper has been benefited largely from anonymous reviewers.

\section{Competing interests}

The authors declare that they have no competing interests.

Received: 30 July 2016 Accepted: 1 January 2017

Published online: 14 January 2017

\section{References}

Agarwal C, Green GM, Grove JM, Evans TP, Schweik CM (2002) A review and assessment of land-use change models: dynamics of space, time, and human choice. General Technical Report NE-297, Newtown Square, pp $1-61$

Alemu B, Garedew E, Eshetu Z, Kassa H (2015) Land use and land cover changes and associated driving forces in north western lowlands of Ethiopia. Int Res J Agric Sci Soil Sci 5(1):28-44

Badege B (2001) Defforestation and land degradation in the ethiopian highlands: strategy for physical recovery. Northeast Afr Stud 8(1):7-26

Bürgi M, Hersperger A, Schneeberger N (2004) Driving forces of landscape change-current and new directions. Landsc Ecol 19:857-868

CSA (1991) The population and housing census of Ethiopia: results at a country level (1984). Office of population and housing census commission. Central Statistical Authority (CSA), Addis Ababa

CSA (1995) The population and housing census of Ethiopia: results at a country level (1994). Office of population and housing census commission. Central Statistical Authority (CSA), Addis Ababa

CSA (2008) The population and housing census of Ethiopia: results at a country level (2007). Office of population and housing census commission. Central Statistical Authority (CSA), Addis Ababa

Dera wereda ARD office. (2013). Dera Wereda ARD office report of 2013. Anbessame, Amhara NRS, Ethiopia (Unpublished)

Eleni Y, Wolfgang W, Michael E, Dagnachew L, Günter B (2013) Identifying land use/cover dynamics in the koga catchment, Ethiopia, from multi-scale data, and implications for environmental change. ISPRS Int J Geo Inf 2:302-323

Eyayu M, Heluf G, Tekalign M, Mohammed A (2009) Effects of land-use change on selected soil properties in the tara gedam catchment and adjacent agro-ecosystems, North West Ethiopia. Ethiop J Nat Res 11:35-62

FAO (1997) The digital soil and terrain database of East Africa (SEA): notes on the Arc/info files, Version 1.0. Land and Water Development Division, Food and Agriculture Organization (FAO), Rome

Driessen P, Deckers J (2001) Lecture notes on the major soils of the World. World Soil Reports 94 (eds). Food and Agriculture organization (FAO), Rome

Getachew F, Heluf G, Kibebew K, Birru Y, Bobe B (2011) Analysis of land use/ land cover changes in the Debre-Mewi watershed at the upper catchment of the Blue Nile Basin, Northwest Ethiopia. J Biodivers Environ Sci 1(6):184-198 
GSE (1996). Geological map of Ethiopia. Scale 1:2,000,000. Addis Ababa, Ethiopia. Ministry of Mines, Geological Survey of Ethiopia, second editions

Hassen MY, Mohammed A, Assefa M, Tena A (2015) Detecting land use/land cover changes in the Lake Hayq (Ethiopia) drainage basin, 1957-2007. Lakes Reserv 20:1-18

Hurni H (1988) Degradation and conservation of the resources in the Ethiopian highlands. Mt Res Dev 8(2/3):123-130

Hurni H (1998) Agroecological belts of Ethiopia: explanatory notes on three maps at a scale of 1:1,000,000. Soil Conservation Research Programme, Addis Ababa

Hurni H, Kebede T, Gete Z (2005) The implications of changes in population, land use, and land management for surface runoff in the upper Nile basin area of Ethiopia. Mt Res Dev 25(2):147-154

Lambin EF, Geist HJ (2006) Land use and land cover change: local processes and global impacts. Springer, Berlin

Lambin EF et al (2001) The causes of land-use and land-cover change: moving beyond the myths. Glob Environ Chang 11:261-269

Lambin EF, Geist HJ, Lepers E (2003) Dynamics of land-use and land-cover change in tropical regions. Annu Rev Environ Res 28:205-241

Lillesand TM, Kiefer RW (1994) Remote sensing and image interpretation. Wiley, New York

Mekuria AD (2005) Forest conversion-soil degradation-farmers' perception nexus: implications for sustainable land use in the southwest of Ethiopia. Cuvillier Verlag Göttingen, Ecol Dev Ser, p 26

Mohammed A (2011) Land use/cover dynamics and its implications in the dried lake Alemaya watershed, eastern Ethiopia. J Sustain Dev Afr 13(4):1-18

Mohammed A, Le Roux PA, Barker CH, Heluf G (2005) Soils of Jelo micro-catchment in the chercher highlands of eastern Ethiopia: I morphological and physicochemical properties. Alemaya, Ethiopia
Sharma A, Tiwari KN, Bhadoria PBS (2011) Effect of land use land cover change on soil erosion potential in an agricultural watershed. Environ Monit Assess 173:789-801

Sherbinin A (2002) A CIESIN thematic guide to land-use and land-cover change (LUCC). Columbia University, Palisades

Tsehaye G, Mohammed A (2013) Effects of slope aspect and vegetation types on selected soil properties in a dryland Hirmi watershed and adjacent agro-ecosystem, northern highlands of Ethiopia. Afr J Ecol 52:1-8

Tsehaye G, Mohammed A (2015) Land use/land cover dynamics and their driving forces in the Hirmi watershed and its adjacent agro-ecosystem, highlands of Northern Ethiopia. J Land Use Sci 10(1):81-94

Veldkamp A, Lambin EF (2001) Predicting land-use change. Agric Ecosyst Environ 85:1-6

Verheye WH (2007) Factors affecting land use and land cover change, Volume 1. In: Briassoulis, land use, land cover and soil sciences (9). Mytilini

Warra HH, Mohammed AA, Nicolau MD (2013) Spatio-temporal impact of socio-economic practices on land use/land cover in the kasso catchment, bale mountains, Ethiopia. Scientific Annals of "Alexandru loan Cuza" University of IAŞI, Volume LIX, no.1, S. II C, Geography series, 1-26

Woldeamlak B (2002) Land cover dynamics since the 1950s in chemoga watershed, Blue Nile Basin. Mt Res Dev 22(3):263-269

Woldeamlak B, Sterk G (2005) Dynamics in land cover and its effect on stream flow in the chemoga watershed, blue Nile basin, Ethiopia. Hydrol Process 19:445-458

Wubalem T (2012) The status of forestry development in Ethiopia: challenges and opportunities. National dialog on sustainable agricultural intensification in ethiopia and its role on the climate resilient green economy initiative in Ethiopia July 23rd and 24th, 2012, ILRI Campus, Addis Ababa

\section{Submit your manuscript to a SpringerOpen ${ }^{\circ}$ journal and benefit from:}

- Convenient online submission

- Rigorous peer review

- Immediate publication on acceptance

- Open access: articles freely available online

- High visibility within the field

- Retaining the copyright to your article

Submit your next manuscript at springeropen.com 